Juli - Desember 2020: 226 - 245

\title{
ANALISIS PERBANDINGAN IMBAL HASIL INVESTASI PRODUK REKSADANA SYARIAH BERIMBANG DAN REKSADANA ANGGREK DI DANAREKSA SEKURITAS CABANG MEDAN
}

\author{
Azizatur Rahmah \\ STAIN Mandailing Natal \\ azizaturrahmah@stain-madina.ac.id
}

\begin{abstract}
Balanced Sharia Mutual Fund Product apply a cleaning or filtering process in the securities portfolio construction. The screening process carried out by removing the income obtained from activities thet are not in accordance with Islamic principles. This process raises doubts about the performance of this mutual fund. Investors also assume that the return on investment in Balanced Sharia Mutual Funds is not as large as the return on investment in the Orchid Mutual Fund. In this period, there is data that shows Balanced Sharia Mutual Funds experienced more profits than Anggrek Mutual Funds by 23 times. Even though during the research period Balanced Sharia Mutual Fund often provide higher invsetmen returns, Orchid Mutual Funds have also experienced the same thing. The results of calculations using the t-test method obtained t-count of 11.93 . Thus $t$-stat $>$ from $t$-table or $11.93>2.807$. The $t$-stat value is obtained from the difference in the percentage of return on investment in the Orchid Mutual Fund minus the yeild for Balanced Sharia Mutual Funds of 171.77 divided by a deviation of 14.38. The conclusion of this study is that there are data that show Balanced Sharia Mutual Funds experience more benefits than Orchid Mutual Funds.

Keywords: balanced sharia mutual funds, anggrek mutual funds, portfolio, returns, risk
\end{abstract}

\begin{abstract}
Abstrak
Produk Reksa Dana Syariah Berimbang memberlakukan proses pembersihan atau penyaringan dalam konsturksi portofolio efek. Proses penyaringan dilakukan dengan mengeluarkan pendapatan yang didapat dari kegiatan yang tidak sesuai dengan prinsip Islam. Proses ini menimbulkan keraguan investor akan kinerja reksa dana ini. Investor juga beranggapan imbal hasil investasi Reksa Dana Syariah Berimbang tidak sebesar imbal hasil investasi Reksa Dana Anggrek. Pada periode ini terdapat data yang menunjukkan Reksa Dana Syariah Berimbang mengalami keuntungan yang lebih dibandingkan Reksa Dana Anggrek sebanyak 23 kali Meskipun pada periode penelitian Reksa Dana Syariah Berimbang sering memberikan imbal hasil investasi yang lebih tinggi Reksa Dana Anggrek juga pernah mengalami hal yang sama. Hasil perhitungan dengan menggunakan metode uji-t didapat t-hitung sebesar 11,93 dengan demikian t-hitung $>$ dari t-tabel atau 11,93 > 2,807. Nilai t-hitung didapat dari selisih persentasi imbal hasil investasi Reksa Dana Anggrek dikurangi imbal hasil Reksa Dana Syariah Berimbang sebesar 171,77 dibagi deviasi sebesar 14,38. Kesimpulan dari penelitian ini terdapat data yang menunjukkan Reksadana Syariah Berimbang mengalami keuntungan yang lebih dibandingankan Reksadana Anggrek.

Kata Kunci: reksa dana syariah berimbang, reksa dana anggrek, imbal hasil, portofolio, resiko
\end{abstract}




\section{Pendahuluan}

Pasar modal merupakan pasar tempat pertemuan dan melakukan transaksi antara para pencari dana (emiten) dengan penanam modal (investor). Dalam pasar modal yang diperjual belikan adalah efek-efek seperti saham dan obligasi dimana jika diukur dari waktunya modal yang diperjualbelikan merupakan modal jangka panjang. ${ }^{1}$ Pasar modal mempunyai peran yang strategis dalam pembangunan nasional, yakni sebagai salah satu sumber pembiayaan bagi dunia usaha dan juga sebagai sarana investasi bagi masyarakat. Oleh karena itu, pasar modal harus dikelola secara teratur, wajar, dan efisien, diperlukan mekanisme pasar modal yang melibatkan instansi pemerintah dan lembaga swasta.

Pasar modal dimanfaatkan oleh perusahaan untuk mencari dana dan selanjutnya digunakan untuk melakukan investasi. Untuk menciptakan mekanisme pasar modal yang baik, diperlukan adanya lembaga yang mengatur pasar modal, lembaga tersebut adalah Badan Pengawas Pasar Modal (Bapepam) atas nama Departemen Keuangan. Bapepam memiliki tugas dan tanggung jawab sebagai pelaksana bursa efek di Indonesia sehingga harus setiap saat mengawasi aktivitas di bursa efek, selain bertugas membina pelaku bursa efek serta mengatur agar bursa efek berjalan dengan baik. ${ }^{2}$

Instrumen pasar modal pada prinsipnya adalah semua surat-surat berharga atau efek yang umumnya diperjualbelikan di pasar modal. Yang dimaksud dengan efek adalah setiap surat pengakuan hutang, surat berharga komersial, saham, obligasi, right, warrants, opsi atau setiap derifatif. Setiap efek yang diperjualbelikan di pasar modal biasanya berjangka waktu panjang. ${ }^{3}$ Dalam kinerja pasar modal syariah terdapat indikator yang dapat digunakan seperti: obligasi syariah atau sukuk, saham syariah, reksadana syariah. ${ }^{4}$ Reksadana memiliki andil yang amat besar dalam perekonomian nasional karena dapat memobilisasi dana untuk pertumbuhan dan pengembangan perusahaan-perusahaan nasional, baik BUMN maupun swasta. Di sisi lain, reksa dana memberikan keuntungan bagi masyarakat berupa keamanan dan keuntungan materi yang meningkatkan kesejahteraan material. ${ }^{5}$ 
AT-TAWASSUTH: Jurnal Ekonomi Islam, Volume V No. 2

Juli - Desember 2020: 226 - 245

Reksa dana berasal dari kata reksa yang berarti jaga atau pelihara, dan kata dana yang artinya uang, sehingga reksa dana dapat diartikan sebagai kumpulan uang yang dipelihara. Menurut Undang-Undang No.8 Tahun 1995 tentang Pasar Modal yang dimaksud reksa dana adalah wadah yang digunakan untuk menghimpun dana dari masyarakat pemodal, untuk selanjutnya diinvestasikan kembali dalam bentuk portofolio efek oleh manajer investasi.

Ada tiga hal yang terkait dari defenisi tersebut antara lain: (1) adanya dana dari masyarakat investor (2) dana tersebut diinvestasikan dalam portofolio efek, (3) dana tersebut dikelola oleh manajer investasi. Dengan demikian, dana yang ada dalam reksa dana merupakan dana bersama para investor, sedangkan manajer investasi adalah pihak yang dipercaya untuk mengelola dana tersebut. Sedangkan reksa dana syariah mengandung pengertian sebagai reksa dana yang pengelolaan dan kebijakan investasinya mengacu kepada syariat Islam.

Reksadana syariah mengandung pengertian sebagai reksadana yang pengelolaan dan kebijakan investasinya mengacu pada syariat Islam. Instrumen investasi yang dipilih dalam portofolionya haruslah yang dikategorikan halal. Dikatakan halal, jika pihak yang menerbitkan instrumen investasi tersebut tidak melakukan usaha yang bertentangan dengan prinsip-prinsip Islam, seperti tidak melakukan riba, maysir dan gharar. Jadi saham, obligasi dan sekuritas lainnya uang dikeluarkan perusahaan yang berhubungan dengan produksi atau penjualan minuman keras, rokok, produk mengandung babi, bisnis hiburan berbau maksiat, bisnis senjata, perjudian, pornografi dan sebagainya tidak dimasukkan ke dalam portofolio reksadana syariah. ${ }^{6}$

Di Indonesia reksa dana syariah pertama dibentuk dengan nama Danareksa Syariah yang disahkan keberadaannya oleh Bapepam pada tanggal 12 Juni 1997. Reksa dana Syariah yang didirikan itu berbentuk Kontrak Investasi Kolektif (KIK) berdasarkan Undang-Undang No.8 Tahun 1995 tentang pasar modal, yang dituangkan dalam Akta Nomor 24 tanggal 12 Juni 1997 yang dibuat dihadapan Notaris Djejem Wijaya, SH di Jakarta antara PT. Danareksa Fund Management sebagai manajer investasi dengan Citibank N.A. Jakarta sebagai Bank Kustodian. PT. Danareksa Fund 
Azizatur Rahmah: Analisis Perbandingan Imbal Hasil Investasi | 229

Management sendiri sebagai manajer investasi didirikan pada tanggal 1 Juli 1992, yang kemudian dilegitimasi oleh Menteri Kehakiman RI dengan surat keputusan nomor C2/7283.HT.01.TH.92 tanggal 3 September 1992.

Menyusul kemudian PT. Nasional Madani (PNM) melalui PNM Investment Management, terbitlah PNM Syariah dan PNM Dana Sejahtera yang keduanya merupakan jenis reksa dana syariah. Agustus 2004 Manajer Investasi PT. Andalan Artha Advisindo (AAA) Sekuritas bekerjasama dengan unit usaha Bank Danamon Syariah meluncurkan produk reksa dana AAA Syariah Fund. November 2004 Bank Syariah Mandiri mengeluarkan produk reksa dana syariah, bekerjasama dengan Mandiri Sekuritas selaku manajer investasi dan Dutche Bank sebagai Bank Kustodian. Desember 2004 Manajemen PT. Bhakti Aset Management (BAM) mengeluarkan produk BIG Dana Syariah yang merupakan reksa dana terbuka berbentuk KIK. Terakhir sampai dengan tahun 2008 menurut data DSN MUI sudah hadir 22 reksa dana syariah di tanah air. ${ }^{7}$

Reksadana syariah di Indonesia mengalami perkembangan yang sangat pesat. Pada tahun 2004, reksadana syariah menunjukkan pertumbuhan yang pesat, ditandai dengan diterbitkannya 7 reksadana syariah yang mendorong peningkatan Nilai Aktiva Bersih (NAB) reksadana syariah sebesar Rp. 459 miliar (586,2\%). Sepanjang tahun 2005, secara umum pasar reksadana nasional mengalami rendemption yang sangat signifikan sehingga terjadi penurunan NAB. Hal yang sama juga dialami sejumlah reksadana syariah dengan total losspenurunan NAB mencapai Rp. 204 miliar.

Sebuah tantangan baru bagi investor muslim apakah investasi syariah mampu mengungguli return dari investasi reksadana konvensional.Dari fenomena tersebut penulis ingin membandingkan ada tidaknya perbedaan imbal hasil antara Reksa dana Syariah Berimbang dengan Reksadana Anggrek. Sehingga para investor tidak ragu lagi menginvestasikan dananya pada Reksadana Syariah Berimbang karena selain memperolah keuntungan investor juga memperoleh barokah. Reksa dana Syariah Berimbang sendiri memiliki tujuan investasi yang sama dengan Reksa dana Anggrek yang membedakannya hanya proses screening. 
230 |AT-TAWASSUTH: Jurnal Ekonomi Islam, Volume V No. 2

Juli - Desember 2020: 226 - 245

Hadirnya lembaga keuangan syariah menimbulkan sikap optimis meningkatnya gairah investasi yang berbasis pada investor muslim. Bapepam mulai melakukan inisiatif untuk mewadahi investor muslim, maka mulai tahun 1997 dihadirkan reksadana syariah dengan produknya bernama danareksa syariah. ${ }^{8}$ Segencar apapun fatwa disebarluaskan. Pertimbangan keuntungan yang akan diterima, tetap menjadi pertimbangan pertama bagi investor untuk menanamkan modalnya. Tidak terkecuali investor muslim dalam memutuskan unntuk berinvestasi pada produk syariah.

\section{Kajian Teori}

\section{Investasi}

Dalam islam investasi merupakan kegiatan muamalah yang sangat dianjurkan karena dengan berinvestasi harta yang dimiliki menjadi produktif dan juga mendatangkan manfaat bagi orang lain. Konsep investasi selain sebagai pengetahuan juga bernuansa spritual karena menggunakan norma syariah, sekaligus merupakan hakikat dari sebuah ilmu dan amal, oleh karenanya investasi sangat dianjurkan bagi setiap muslim. ${ }^{9}$

Secara umum bentuk - bentuk investasi ada 2 macam yaitu :

1) Investasi nyata adalah investasi dalam bentuk yang dapat dilihat fisik, seperti emas, intan, perak, rumah, tanah, ruko dan lain sebagainya.

2) Investasi keuangan adalah investasi dalam bentuk yang biasanya diwakilkan dalam bentuk-bentuk surat-surat berharga, seperti surat berharga, deposito dan lain sebagainya. ${ }^{10}$

\section{Reksadana Syariah dan Reksadana Konvensional}

Reksadana berasal dari kata reksa yang berarti jaga atau pelihara dan kata dana berarti uang. Sehingga reksa dana dapat diartikan sebagai kumpulan uang yang dipelihara. Reksa dana pada umumnya diartikan sebagai wadah yang dpergunakan untuk menghimpun dana dari masyarakat pemodal untuk selanjutnya diinvestasikan dalam portofolio efek (saham, obligasi, valuta asing atau deposito) oleh manager investasi. $^{11}$ Dalam Peraturan Otoritas Jasa Keuangan ini yang dimaksud dengan Reksa Dana Syariah adalah Reksa Dana sebagaimana dimaksud dalam Undang- 
Undang tentang Pasar Modal dan peraturan pelaksanaannya yang pengelolaannya tidak bertentangan dengan Prinsip Syariah di Pasar Modal. ${ }^{12}$

Reksadana syariah mengandung pengertian sebagai reksadana yang pengelolaan dan kebijakan investasinya mengacu pada syariat Islam. Instrumen investasi yang dipilih dalam portofolionya haruslah yang dikategorikan halal. Dikatakan halal, jika pihak yang menerbitkan instrumen investasi tersebut tidak melakukan usaha yang bertentangan dengan prinsip-prinsip Islam, seperti tidak melakukan riba, maysir dan gharar. Jadi saham, obligasi dan sekuritas lainnya uang dikeluarkan perusahaan yang berhubungan dengan produksi atau penjualan minuman keras, rokok, produk mengandung babi, bisnis hiburan berbau maksiat, bisnis senjata, perjudian, pornografi dan sebagainya tidak dimasukkan ke dalam portofolio reksadana syariah. $^{13}$

Berdasarkan sifat operasionalnya, reksa dana dapat dibedakan dalam dua jenis, yaitu reksa dana tertutup dan reksadana terbuka. Reksa dana yang berbentuk perseroan (PT) dapat bersifat tertutup dan terbuka, sedangkan reksa dana yang berbentuk KIK hanya dapat bersifat terbuka. ${ }^{14}$

\section{Reksadana Syariah Berimbang dan Reksadana Anggrek}

Reksa Dana syariah berimbang adalah reksa dana terbuka berbentuk kontrak investsi kolektif yang dituangkan dalam akta nomor 31 tanggal 15 November 2000. Reksa dana syariah berimbang mulai ditawarkan kepada masyarkat pada tanggal 1 Desember 2000 dengan harga Rp. 1.000,- (seribu rupiah) per unit penyertaannya dan penawaran dilaksanakan secara terus menerus hingga mencapai 1.000.000.000,- ( satu miliar) unit penyertaan. Harga unit penyertaan setelah tanggal 1 Desember 2000 ditentukan sesuai dengan nilai aktiva bersih portofolio danareksa syariah berimbang pada akhir hari bursa yang bersangkutan.

Manajer investasi dapat sewaktu-waktu menambah jumlah unit penyertaan reksa dana syariah berimbang yang ditawarkan setelah mendapat persetujuan BAPEPAM. Reksa dana syariah berimbang bertujuan untuk mendapatkan pertumbuhan nilai investasi dalam jangka panjang dan memperoleh pendapat yang berkelanjutan kepada pemodal yang hendak mengikuti syariat Islam. Kekayaan Reksa 
dana syariah berimbang akan diinvestasikan minimum 25\% hingga maksimum $75 \%$ dalam efek bersifat ekuitas: minimum 25\% hingga maksimum $75 \%$ dalam efek bersifat hutang dan intrumen pasar uang dengan mengikuti syariah Islam.

Karateristik Reksa dana syariah berimbang:

a) Balasan investasi

Reksa dana syariah berimbang tidak akan membeli saham yang diterbitkan oleh perusahaan yang jenis dan ruang lingkup kegiatan usahanya tidak sesuai dengan prinsip syariah Islam, yang perusahaannya memproduksi, memakai atau meberikan jasa-jasa yang tidak sesuai dengan syariah Islam.

b) Keberadaan dewan pengawas syariah-dewan syariah nasional

Dewan pengawas syariah bertugas memberikan arahan kegiatan manajer investasi agar senantiasa sesuai dengan syariah Islam.

c) Tata cara investasi

Investasi dalam Reksa dana syariah berimbang dilakukan dengan menghindar dari gharar (resiko yang tidak wajar) dan maysir (bersifat judi)

d) Penyisihan pendapat

Pendapat yang tidak sesuai dengan syariat Islam harus disisikan dan dikeluarkan dari hasil reksa dana syariah berimbang dalam bentuk shadaqah. Penyaluran shadaqah ini akan diaudit dan dilaporkan dalam laporan keuangan.

e) Penyaluran Zakat Maal

Manajer investasi menawarkan jasa untuk memotong dan menyalurkan Zakat Maal para pemodal.

Reksa dana Anggrek adalah reksa dana yang berbentuk kontrak investasi kolektif yang dituangkan dalam akta nomor 10 tanggal 3 Juli 1996 dan addendum kontrak investasi kolektif danareksa anggrek nomor 4 tanggal 4 Juli 1996. Danareksa anggrek ditawarkan kepada masyarakat dengan harga sama dengan nilai aktivasi bersih awal sebesar Rp.1000 (seribu rupiah) per unit penyertaan dan penawaran dilaksanakan secara terus-menerus sehingga mencapai 500.000.000,- (lima ratus juta) unit penyertaan. Harga pembelian dan penjualan kembali unit penyertaan selanjutnya adalah sebesar nilai aktiva bersih per unit penyertaan pada akhir hari bursa yang 
bersangkutan. Manajer investasi dapat menambah jumlah unit penyertaan danareksa anggrek yang ditawarkan setelah mendapat persetujuan dari BAPEPAM.

Reksa dana Anggrek bertujuan untuk memperoleh pertumbuhan nilai investasi yang optimal dalam jangka panjang namun tetap memberikan pandapat yang memadai melalui investasi pada efek Ekuitas dan efek hutang dan instrumen pasar uang. Kinerja Reksa dana Anggrek diukur berdasarkan tingkat hasil yang bersangkutan (Current yield) yang diperoleh dari pembagian uang minimal sekali setahun dan pertumbuhan nilai aktiva bersih. Tolak ukur kinerja danareksa anggrek adalah tingkat investasi bersih rata-rata pada deposito bank-bank pemerintah untuk jangka waktu 6 (enam) bulan dan pertumbuhan Index Harga Saham Gabungan (ISHG) dengan perbandingan 40\%:60\%.

\section{Imbal Hasil}

Sebelum menginvestasikan dananya investor selalu mempertimbangkan jumlah imbal hasil investasi yang akan didapat pada masa yang akan dating jika investor menginvestasikan dananya saat ini. Menurut Jogianto, imbal hasil merupakan hasil yang diperoleh dari investasi. ${ }^{1}$ Menurut Abdul Halim, imbal hasil adalah imbalan yang didapat dari investasi. Imbal hasil dapat berupa imbal hasil realisasi dan imbal hasil ekspektasi. ${ }^{2}$

1) Imbal hasil realisasi merupakan imbal hasil yang kita dapat setelah melakukan investasi. Imbal hasil realisasi dihitung berdasarkan data sejarah. Imbal hasil realisasi penting karena digunakan sebagai salah satu pengukur kinerja perusahaan. Imbal hasil ini juga berguna sebagai dasar penentu imbal hasil ekpektasi dan resiko masa mendatang.

2) Imbal hasil Ekspektasi adalah imbal hasil yang diharapkan akan diperoleh oleh investor masa mendatang. Manajer investasi di pasar modal. Sehingga investor dapat mempertimbangkan produk yang sesuai dengan keinginannya.

Dalam investasi keuangan jangka panjang imbal hasil investasi yang dapat diterima oleh reksa dana syariah, antara lain:

\footnotetext{
${ }^{1}$ Jogianto, Teori Portofolio dan Analisis Investasi, Edisi ke-2 (Yogyakarta: BPFE, 2000), hlm:

${ }^{2}$ Abdul Halim, Ananlisis Investasi,(Jakarta: Salemba, 2003), hlm: 30.
} 109. 
234 AT-TAWASSUTH: Jurnal Ekonomi Islam, Volume V No. 2

Juli - Desember 2020: 226 - 245

a) Dari saham berupa:

$>$ Dividen yang merupakan bagi hasil atas keuntungan yang dibagikan dari laba yang dihasilkan emiten, baik dibayarkan dalam bentuk tunai maupun dalam bentuk saham.

$>$ Right yang merupakan hak untuk memesan efek lebih dahulu yang diberikan oleh emiten.

$>$ Capital gain yang merupakan keuntungan yang diperoleh dari jual beli saham di pasar modal.

b) Dari Obligasi yang sesuai dengan syariah dapat berupa bagi hasil yang diterima secara periodik dari laba emiten.

c) Dari surat berharga pasar uang yang sesuai dengan syariah dapat berupa bagi hasil yang diterima dari issuer.

d) Dari deposito dapat berupa bagi hasil yang diterima dari bank syariah.

\section{Indeks Harga Saham}

Indeks harga saham (IHS) merupakan ringkasan dari pengaruh simultan dan kompleks dari bermacam variabel yang berpengaruh pada kejadian-kejadian ekonomi, sosial, politik dan keamanan. Agar dapat melakukan investasi di pasar modal dengan baik maka investor harus mengetahui IHS. Di Bursa Efek Indonesia (BEI), indeks sektoral terbagi atas tiga sektor usaha yaitu, sektor usaha primer, manufaktur dan usaha jasa. ${ }^{3}$

Dalam rangka mengembangkan pasar modal syariah, PT. Bursa Efek Indonesia bersama dengan PT. Danareksa Sekuritas meluncurkan indeks saham yang disusun berdasarkan prinsip Islam, yaitu Jakarta Islamic Index (JII). JII terdiri dari 30 saham yang dipilih dari saham-saham yang sesuai prinsip Islam. Dengan adanya JII diharapkan dapat meningkatkan kepercayaan investor untuk mengembangkan investasi dalam pasar modal secara Islami. ${ }^{4}$

\section{Resiko}

\footnotetext{
${ }^{3}$ Halim, Analisis, hlm: 45 .

${ }^{4}$ Jogianto, Teori Portofolio, hlm: 110.
} 
Resiko dalam berinvestasi yang mungkin timbul dan perlu dipertimbangkan dalam membuat keputusan dalam berinvestasi dengan jenis sebagai berikut:

1) Resiko bisnis (business risk)

2) Resiko likuiditas (liquidity risk)

3) Resiko tingkat bunga (interest rate risk)

4) Resiko pasar (market risk)

5) Resiko daya beli (purchasing power risk)

6) Resiko mata uang (currency risk). ${ }^{5}$

Resiko yang akan dihadapi apabila berinvestasi di reksa dana adalah:

1) Resiko berkurangnya Nilai Unit Penyertaan (NUP)

2) Resiko likuiditas

3) Resiko wanprestsi

4) Resiko-resiko lain seperti resiko ekonomi dan politik, pasar, inflasi, dan nilai tukar. $^{6}$

\section{Hubungan antara Return Ekspektasi dengan Resiko}

Return dan resiko merupakan hal yang tidak terpisahkan, karena pertimbangan suatu investasi merupakan trade off dari kedua faktor ini. Hubungan yang semakin positif, semakin besar resiko yang harus ditanggung semakin besar return yang diharapkan. Untuk menghitung resiko, metode yang banyak digunakan adalah deviasi standart yang mengukur absolute penyimpangan nilai-nilai yang sudah terjadi dengan nilai ekspektasinya. ${ }^{7}$

\section{Aset Beresiko dan Aset Bebas Resiko}

Dalam berinvestasi, investor dapat memilih dalam menginvestasikan pada berbagai aset baik aset beresiko maupun aset yang bebas resiko atau kombinasi dari kedua aset tersebut. Pilihan investor pada aset-aset tersebut tergantung dari sejauh mana prefensi investor terhadap resiko. Semakin enggan investor terhadap resiko, maka pilihan investasinya cenderung pada investasi-investasi bebas resiko. Aset beresiko adalah aset-aset yang tingkat aktualnya dimasa depan masih mengandung

\footnotetext{
${ }^{5}$ Abdul Hamid, Analisis Investasi (Jakarta: Salemba Emban Patria, 2005), hlm: 205.

${ }^{6}$ Ibid, hlm: 206-207.

${ }^{7}$ http://jurnal.pdii.lipi.go.id/admin/jurnal, diakses pada tanggal 1 juli 2013
} 
ketidak pastian. Salah satu contoh aset beresiko adalah saham sedangkan contoh aset bebas resiko merupakan aset yang tingkat pengembaliannya di masa depan sudah bisa dipastikan pada saat ini dan ditujukan oleh varians return yang sama dengan nol.

\section{Metode Penelitian}

Penelitian ini menggunakan pendekatan kuantitatif, yaitu suatu metode penelitian dimana data yang diperoleh berupa angka-angka atau pernyataan yang dinilai dan dianalisis. Penelitian ini khusus membahas tentang imbal hasil produk investasi di Reksa dana Syariah Berimbang dan Reksa dana Anggrek yang dikelola oleh manajer investasi PT. Danareksa Sekuritas Cabang Medan. Adapun teknik pengumpulan data yang digunakan dalam penelitian ini adalah studi dokumentasi yaitu, melalui informasi yang bersumber dari data-data sekunder yang berasal dari laporan tingkat pengembalian dan resiko PT. Danareksa Sekuritas Cabang Medan serta data yang relevan dengan penelitian ini baik dari pihak perusahaan maupun yang berasal dari buku-buku literatur, jurnal dan internet yang berkaitan dengan penelitian ini.

Analisis data yang digunakan adalah analisis data deskripsi yaitu suatu metode analisi yang dilakukan dengan cara mengumpulkan, mengklarifikasikan, menafsirkkan dan menyajikan data yang diperoleh secara terperinci sehingga dapat digambarkan dengan jelas tentang tingkat pengembelian dan resiko investasi. Dan Analisis perbandingan dengan menggunakan metode uji-t $:^{8}$

$$
t=\frac{\overline{\mathrm{X}} 1-\overline{\mathrm{X}} 2}{s d}
$$

Dimana:

$$
\bar{X}=\frac{\sum \mathrm{x}}{\mathrm{n}}
$$

$$
\mathrm{Sd}=\sqrt{\sum \frac{(x-\bar{X})^{2}}{n-1}}
$$

\section{5), h. 112 .}

${ }^{8}$ Husaini Usman dan R.Purnomo Setiady Akbar, Pengantar Statistik (Jakarta: Bumi Aksara,
} 
Keterangan:

$$
\begin{array}{ll}
\mathrm{Sd} & : \text { Standar Deviasi } \\
\mathrm{t} & : \text { Uji beda } \\
\bar{X} & : \text { Beda tingkat pengembalian investasi reksadana syari'ah } \\
& \text { berimbang } \\
\mathrm{N} & : \text { jumlah data }
\end{array}
$$

Kriteria pengujian adalah jika t-hitung lebih besar dari t-tabelmaka ha diterima, bila sebaliknya maka ha ditolak atau h0 diterima.

\section{Hasil Dan Pembahasan}

\section{Hasil Penelitian Independen Sample T Test}

Pengujian dalam penelitian ini menggunakan uji-t pada data persentase tingkat pengembalian investasi yang diperoleh investor. Pengujian ini digunakan untuk mengetahui ada tidaknya perbedaan tingkat pengembalian investasi yang diperoleh dari dana yang diinvestasikan di Reksa dana Syariah Berimbang dan Reksa dana Anggrek.

Hasil perhitungan uji-t menggambarkan data imbal hasil investasi reksa dana syariah berimbang total investasi dengan periode penelitian selama 24 bulan sebesar Rp. 126.910.000.000 akan menghasilkan imbal hasil investasi Rp. 11.872.331.000 dan persentasenya 9,35\% . Imbal hasil tertinggi Rp. 6.757.000.000 dengan jumlah investasi sebesar Rp. 10.000.000.000 dengan persentase 67,57\% Berikut ini gambaran grafiknya: 
238 AT-TAWASSUTH: Jurnal Ekonomi Islam, Volume V No. 2

Juli - Desember 2020: 226 - 245

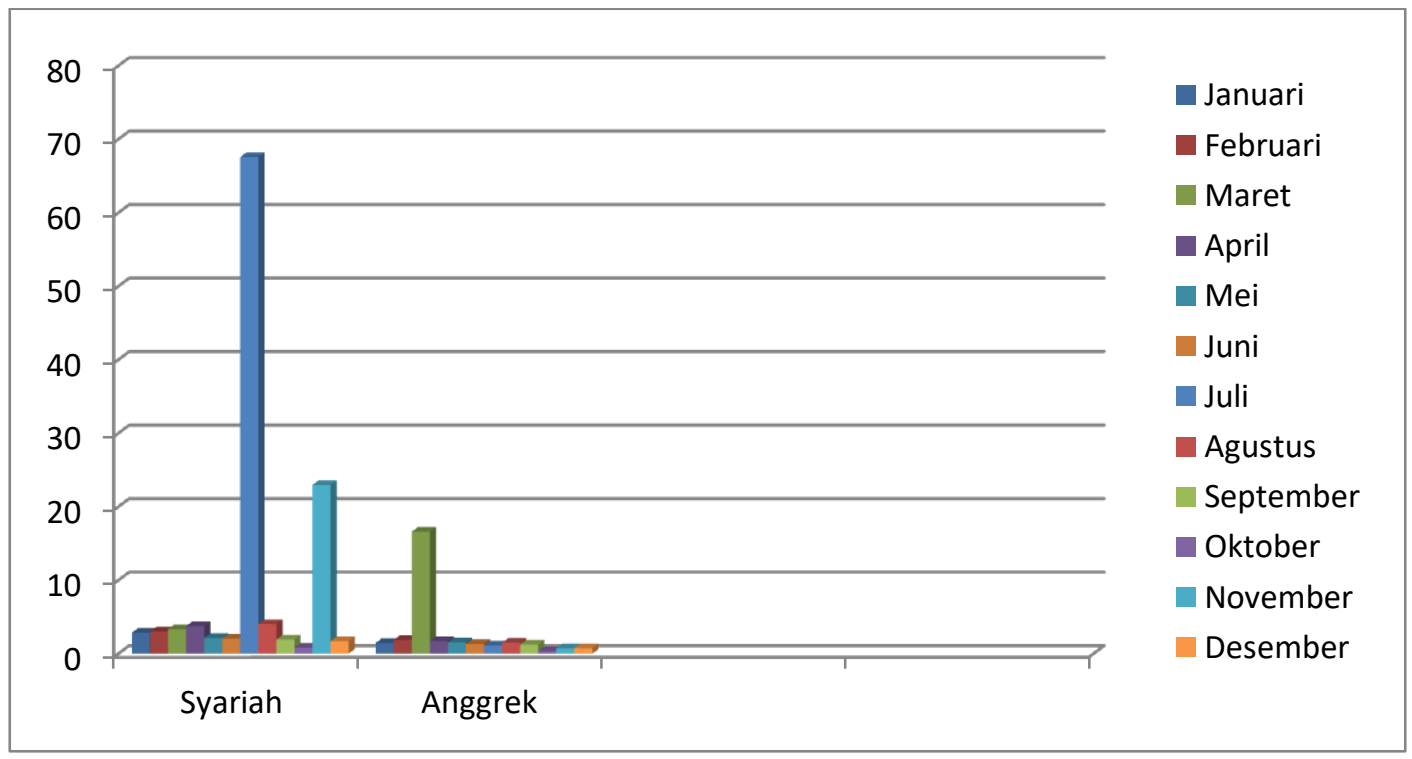

Gambar 1 Grafik Perbandingan Reksa Dana Syariah Berimbang

Grafik menggambarkan imbal hasil investasi Reksa Dana Syariah Berimbang lebih menguntungkan dibandingkan imbal hasil investasi Reksa Dana Anggrek, yaitu terlihat pada Bulan Juli dan November sedangkan Reksa Dana Anggrek hanya mengalami keuntungan yang tinggi hanya pada bulan Maret.

\section{Imbal Hasil Investasi Reksa Dana Syariah Berimbang}

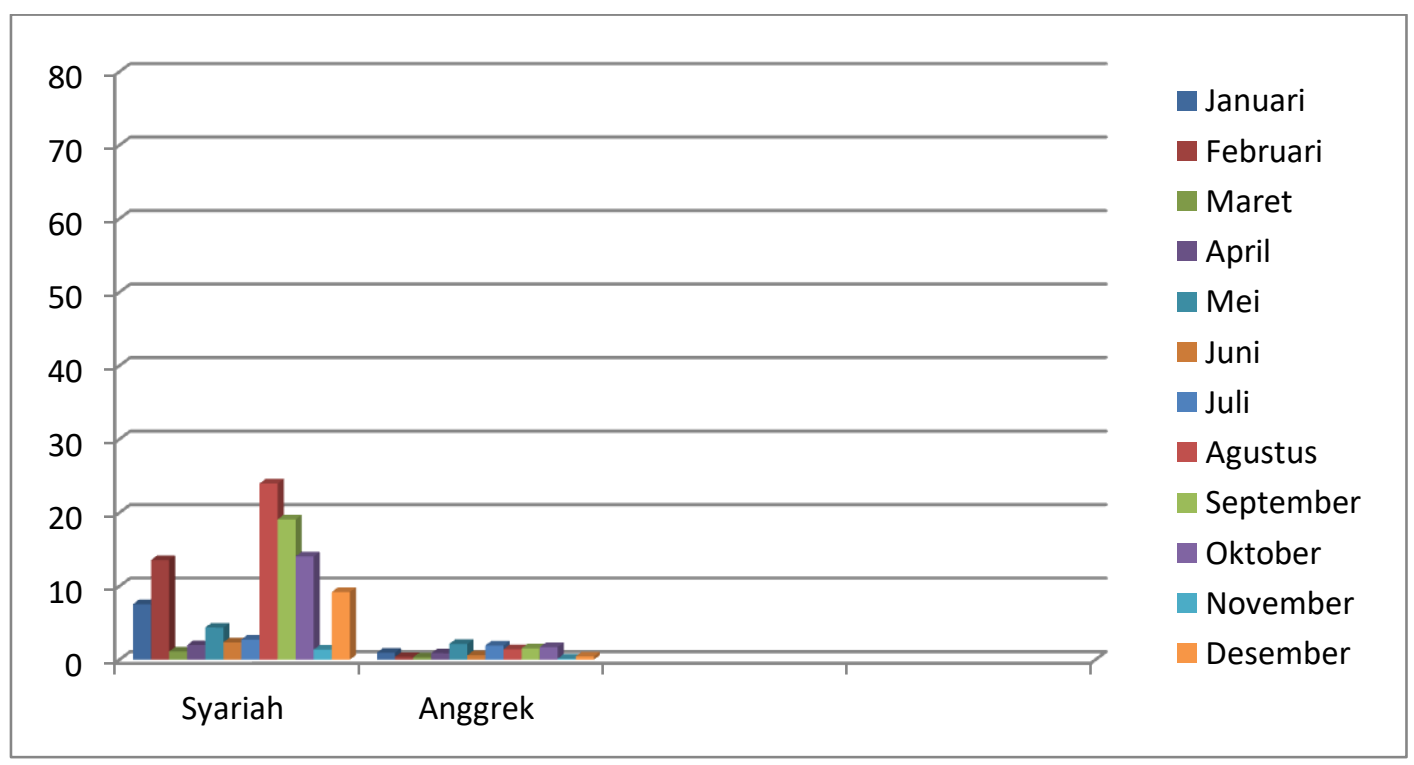

Gambar 2 Grafik Hasil Investasi Reksa Dana Anggrek 
Grafik menggambarkan imbal hasil investasi Reksa Dana Anggrek sangat menurun sedangkan imbal hasil investasi reksadana syariah berimbang melebihi reksa dana anggrek. Pada Reksa Dana Anggrek sebesar Rp. 281.270.000.000 maka imbal hasil yang didapat adalah sebesar Rp. 4.873.354.000 dan dengan nilai persentasenya $1,73 \%$. Hal yang menarik dalam penelitian ini, dalam periode penelitian terlihat bahwa dalam periode penelitian imbal hasil investasi di Reksa Dana Syariah Berimbang menggambarkan persentase yang lebih tinggi dibanding dengan Dana Reksa Anggrek.

Untuk lebih memperjelas perbandingan imbal hasil kedua reksadana penulis menggunakan metode uji-t Data dengan konstruksi portofolio atau Microsft Excel. Pengujian dalam penelitian ini menggunakan uji-t pada data persentase imbal hasil investasi yang diperoleh investor. Pengujian ini digunakan untuk mengetahui ada tidaknya perbedaan imbal hasil investasi yang diperoleh dari dana yang diinvestasikan di reksadan syariah berimbang dan reksa dana anggrek. Berikut tabel data yang menggambarkan perhitungan uji-t .

Tabel 3 Kertas Kerja Uji-t Meam Imbal Hasil Investasi Reksa Dana Syariah Berimbang dan Reksa Dana Anggrek

\begin{tabular}{|l|l|l|l|r|}
\hline \multicolumn{1}{|c|}{$\mathbf{X 1}$} & \multicolumn{1}{|c|}{$\mathbf{X} \mathbf{X}$} & \multicolumn{1}{c|}{$(\mathbf{X}-\overline{\boldsymbol{X}})$} & \multicolumn{1}{c|}{$(\mathbf{X}-\mathbf{X})^{\mathbf{2}}$} \\
\hline 2.86 & 1.46 & 1.4 & -5.76 & 33.17 \\
\hline 3.02 & 1.87 & 1.15 & -6.01 & 36.12 \\
\hline 3.34 & 16.66 & -13.32 & -20.48 & 419.43 \\
\hline 3.76 & 1.73 & 2.03 & -5.13 & 26.31 \\
\hline 2.13 & 1.53 & 0.6 & -6.56 & 43.03 \\
\hline 2.05 & 1.34 & 0.71 & -6.45 & 41.60 \\
\hline 67.57 & 1.11 & 63.46 & 56.30 & 3169.69 \\
\hline 4.03 & 1.49 & 2.54 & -4.62 & 21.34 \\
\hline 1.93 & 1.25 & 0.68 & -6.48 & 41.99 \\
\hline 0.82 & 0.34 & 0.48 & -6.68 & 44.62 \\
\hline 22.92 & 0.74 & 22.18 & 15.02 & 225.60 \\
\hline 1.7 & 0.75 & 0.95 & -6.21 & 38.56 \\
\hline 7.55 & 0.96 & 6.59 & -0.57 & 0.32 \\
\hline 13.56 & 0.37 & 13.19 & 6.03 & 36.36 \\
\hline 1.12 & 0.33 & 0.79 & -6.37 & 40.57 \\
\hline 1.99 & 0.88 & 1.11 & -6.05 & 36.30 \\
\hline 4.37 & 2.14 & 2.23 & -4.93 & 24.30 \\
\hline 2.36 & 0.59 & 1.77 & -5.39 & 29.05 \\
\hline 2.75 & 1.94 & 0.84 & -6.35 & 40.32 \\
\hline
\end{tabular}


240 AT-TAWASSUTH: Jurnal Ekonomi Islam, Volume V No. 2

Juli - Desember 2020: 226 - 245

\begin{tabular}{|l|l|l|l|r|}
\hline 23.96 & 1.41 & 22.55 & 15.39 & 236.85 \\
\hline 19.08 & 1.55 & 17.53 & 10.37 & 107.53 \\
\hline 14.06 & 1.7 & 12.36 & 5.20 & 27.04 \\
\hline 1.37 & 0.15 & 1.22 & -5.94 & 35.28 \\
\hline 9.21 & 0.45 & 8,76 & 1.60 & 2.56 \\
\hline
\end{tabular}

Sumber: Data Diolah, 2020.

Keterangan :

$\mathrm{X}=$ hasil perbedaan $\mathrm{X} 1-\mathrm{X} 2$

$\mathrm{Sd}=$ standart deviasi

$\mathrm{N}=$ jumlah sampel

Untuk memperoleh rata-rata $\mathrm{X}$ adalah sebagai berikut ;

$$
\begin{aligned}
X & =\frac{\sum x}{n} \\
& =\frac{171.77}{24} \\
& =7.1570
\end{aligned}
$$

Untuk mengetahui perbandingan imbal hasil investor yang mengisvestasikan dananya pada PT.Dana Reksa sekuritas penulis menggunakan uji-t.sebeleum melakukan penelitian terlebih dahulu harus diketahui level of significant (df) yaitu $\alpha$ $=0,05$ dengan tingkat keyakinan 95\% dan resiko 5\% didapat dari t-tabel sebesar $(\alpha / 2)$ : (n-1) yaitu 2,807. Apabila t-hitung > dari t-tabel maka Ha diterima namun apabila t-hitung < dari t-tabel maka Ha ditolak.

Rumus analisis uji-t yaitu:

$$
\begin{aligned}
S d & =\frac{\sqrt{\sum(x-\bar{x})^{2}}}{n-1} \\
& =\frac{\sqrt{4758.24}}{24-1} \\
& =14.383
\end{aligned}
$$


Dengan diketahuinya beda rata-rata dan standart deviasi maka t hitungan dapat di hitung sebagai berikut:

$$
\begin{gathered}
\mathrm{t}=\frac{\overline{x_{1}}-\overline{x_{2}}}{S d} \\
=\frac{171.77}{14.383} \\
=11.93
\end{gathered}
$$

\section{Pembahasan}

Pada periode ini terdapat data yang menunjukkan Reksa Dana Syariah Berimbang mengalami keuntungan yang lebih dibandingkan Reksa Dana Anggrek sebanyak 23 kali pada periode penelitian ini. Meskipun pada periode penelitian Reksa Dana Syariah Berimbang sering memberikan imbal hasil investasi yang lebih tinggi, namun Reksa Dana Anggrek juga pernah mengalami hal yang sama, yaitu pada bulan Maret.

Untuk mengetahui perbedaan imbal hasil investasi Reksa Dana Syariah Berimbang dan Reksa Dana Anggrek. Digunakan perhitungan uji-t dan konstruksi portofolio dengan Microsoft Excel . hasil perhitungan dengan menggunakan metode uji-t didapat t-hitung sebesar 11,93 dengan demikian t-hitung > dari t-tabel atau 11,93 $>$ 2,807. Nilai t-hitung didapat dari selisih persentasi imbal hasil investasi Reksa Dana Anggrek dikurangi imbal hasil Reksa Dana Syariah Berimbang sebesar 171,77 dibagi deviasi sebesar 14,38.

\section{Kesimpulan}

Berdasarkan hasil analisis yang telah dibahas, peneliti kemudian mengambil kesimpulan dijelaskan dibawah ini:

1) Alokasi dana investor pada Reksa Dana Syariah dikonstruksikan dalam efek ekuitas, efek pasar uang dan efek hutang. Sedangkan Reksa Dana Anggrek mengkonstruksikan dana investor $100 \%$ pada efek ekuitas.

2) Hasil uji-t menunjukkan bahwa t-hitung lebih besar dibandingkan t-tabel yaitu 11,93 > 2,807. Jadi hasil uji hipotesisnya, yaitu Ha diterima dan Ho ditolak karena Ho tidak terbukti. 
242 AT-TAWASSUTH: Jurnal Ekonomi Islam, Volume V No. 2

Juli - Desember 2020: 226 - 245

3) Imbal hasil yang didapat berasal dari bunga, capital gain dan bagi hasil.

4) Reksa Dana Syariah Berimbang mengalami keuntungan sebanyak 23 kali.

Dengan melihat imbal hasil investasi kedua Reksa Dana yaitu Reksa Dana Syariah Berimbang dan Reksa dana Anggrek. Disarankan sebaiknya investor melakukan investasi pada Reksa Dana Syariah Berimbang karena dari hasil perhitungan imbal hasil investasi menunjukkan bahwa imbal hasil investasi dan resiko Reksa Dana Syariah Berimbang lebih baik dari Reksa Dana Anggrek.

\section{Endnote}

${ }^{1}$ Kashmir, Bank dan Lembaga Keuangan Lainnya Ed. Revisi-8 (Jakarta: RajaGrafindo Persada, 2008), hlm. 6.

2 Veithzal Rivai, dkk, Bank and Financial Institution Management Conventional and Shariah System, (Jakarta: RajaGrafindo, 2007), hlm. 936.

${ }^{3}$ Dewi Astuti, Manajemen Keuangan Perusahaan, (Jakarta: Ghalia Indonesia ,2004), hlm. 49.

4 Mustafa Edwin Nasution,et. Al. Pengenalan Eksklusif Ekonomi Islam, (Jakarta: Putra Grafika, 2010), hlm. 302-310.

${ }^{5}$ Majelis Ulama Indonesia, Himpunan Fatwa MUI, (Jakarta: Erlangga,2011), hlm. 367.

${ }^{6}$ Abdul Manan, Aspek Hukum Dalam Penyelenggaraan Investasi di Pasar Modal Syariah Indonesia, (Jakarta: Kencana, 2009), hlm. 150.

${ }^{7}$ Andri Soemitra, Bank dan Lembaga Keuangan Syariah, (Jakarta: Kencana, 2009), hlm. 170-171

8 Heri Sudarsono, Bank \& Lembaga Keuanngan Syariah, (Yogyakarta: Ekosiana, 2003), hlm. 201.

${ }^{9}$ Bodie (dkk), Investment 3 ed, (United States Of America: Irwin Professional Publishing, Inc, 1996), hlm. 325.

${ }^{10}$ Abdul Halim, Analisi Investasi (Jakarta: Salemba, 2003), hlm: 2 
11 Heri Sudarsono, Bank \& Lembaga Keuangan Syariah, (Yogyakarta: Ekosiana, 2003), hlm. 12.

12 Peraturan Otoritas Jasa Keuangan, Tentang Penerbitan dan persyaratan Reksadana Syariah, Nomor 19 /POJK.04/2015, Pasal 1.

13 Abdul Manan, Aspek Hukum Dalam Penyelenggaraan Investasi di Pasar Modal Syariah Indonesia, (Jakarta: Kencana, 2009), hlm. 150.

${ }^{14}$ Andri Soemitra, Keuangan Syariah, hlm. 184-185.

15 Pratomo dan Ubaidilah Nugroho. Reksadana: Solusi Perencanaan Investasi di Era Modern. (Jakarta: Gramedia Pustaka Utama, 2005). Hlm. 127129

${ }^{16}$ Iggi Achsien. Investasi Syariah di Pasar Modal Menggagas Konsep dan Praktek Manajemen Portofolio Syariah. (Jakarta: PT Gramedia Pustaka Utama, 2003). hlm: 29-32

17 Jogianto, Teori Portofolio dan Analisis Investasi, Edisi ke-2. (Yogyakarta: BPFE, 2000), hlm. 109.

18 Abdul Halim. Analisi Investasi. (Jakarta: Salemba, 2003), hlm. 30.

${ }^{19}$ Ibid, hlm. 45.

${ }^{20}$ Jogianto, Teori Portofolio, hlm. 110.

${ }^{21}$ Abdul Hamid, Analisis Investasi, (Jakarta: Salemba Emban Patria, 2005), hlm. 205.

22 Heri Sudarsono, Bank \& Lembaga Keuangan Syari'ah, (Yogyakarta: Ekosiana, 2003), hlm. 206-207.

${ }^{23}$ Ibid, hlm: 206-207.

${ }^{24}$ http://jurnal.pdii.lipi.go.id/admin/jurnal, diakses pada tanggal 1 juli 2020

${ }^{25}$ www. ojk.go.id 
244 AT-TAWASSUTH: Jurnal Ekonomi Islam, Volume V No. 2

Juli - Desember 2020: 226 - 245

\section{Daftar Pustaka}

Achsien, Iggi. ( 2003). . Investasi Syariah di Pasar Modal Menggagas Konsep dan Praktek Manajemen Portofolio Syariah. Cetakan Kedua. Jakarta: PT Gramedia Pustaka Utama,

Astuti, Dewi. (2004). Manajemen Keuangan Perusahaan, Jakarta: Ghalia Indonesia

Bodie (dkk). (1996). Investment 3 ed. United States Of America: Irwin Professional Publishing, Inc

Edwin, Mustafa Nasution,dkk. (2010). Pengenalan Eksklusif Ekonomi Islam. Jakarta: Putra Grafika

Halim, Abdul. (2003) Analisi Investasi. Jakarta: Salemba

Hamid, Abdul. (2005). Analisis Investasi. Jakarta: Salemba Emban Patria

http://jurnal.pdii.lipi.go.id/admin/jurnal, diakses pada tanggal 1 juli 2013

Jogianto. (2000). Teori Portofolio dan Analisis Investasi, Edisi ke-2. Yogyakarta: BPFE

Kashmir. (2008 ). Bank dan Lembaga Keuangan Lainnya Ed. Revisi-8 Tahun. Jakarta: Raja Grafindo Persada

Majelis Ulama Indonesia. (2011). Himpunan Fatwa MUI . Jakarta: Erlangga

Manan, Abdul. (2009). Aspek Hukum Dalam Penyelenggaraan Investasi di Pasar Modal Syariah Indonesia . Jakarta: Kencana

Peraturan Otoritas Jasa Keuangan, Tentang Penerbitan dan persyaratan Reksadana Syariah, Nomor 19 /POJK.04/2015, Pasal 1

Soemitra, Andri. (2009). Bank dan Lembaga Keuangan Syariah. Jakarta: Kencana

Sudarsono, Heri. (2003). Bank \& Lembaga Keuangan Syari'ah. Yogyakarta: Ekosiana

Rivai, Veithzal. (2007). Bank and Financial Institution Management Conventional and Shariah System. Jakarta: Raja Grafindo 
Azizatur Rahmah: Analisis Perbandingan Imbal Hasil Investasi $\mid 245$

Nugroho, Ubaidilah, Pratomo. (2005). Reksadana: Solusi Perencanaan Investasi di Era Modern. Jakarta: Gramedia Pustaka Utama

www.ojk.go.id

www.danareksa.com

www.bij.go.id 